Global Conferences Series:

Sciences and Technology (GCSST), Volume 5, 2020

Seminar Nasional I Baristand Industri Padang (Semnas I BIPD)

DOI:https://doi.org/10.32698/GCS-SNIIBIPD3449

\title{
Application of fresh liquid chlorella as a natural supplement to improve performance and reduce broiler blood cholesterol levels for food safety
}

\section{Aplikasi fresh liquid chlorellasebagai suplemen alami dalam memperbaiki performa dan menurunkan kadar kolesterol darah broiler untuk keamanan pangan}

\author{
Salvia $S^{* 1}$, Irzal Irda ${ }^{1}$, Devi Kumala Sari ${ }^{1}$, Reni Novia ${ }^{2}$, Fatardho Zudri ${ }^{3}$ \\ ${ }^{1}$ Program Studi Budidaya Ternak, Politeknik Pertanian Negeri Payakumbuh, Indonesia \\ ${ }^{2}$ Program Studi Paramedik Veteriner, Politeknik Pertanian Negeri Payakumbuh, Indonesia \\ ${ }^{3}$ Program Studi Pengelolaan Perkebunan, Politeknik Pertanian Negeri Payakumbuh, Indonesia \\ E-mail:salviasani@ymail.com
}

\begin{abstract}
Microalgae have been studied for long as a functional foods and as food supplements for health. Microalgae contain nutrients and act as antimicrobials, natural antioxidants, anti-cholesterol and contain growth hormones. The research objective was to determine the application of fresh liquid chlorella (FLC) as a natural supplement on performance and broiler blood cholesterol for food safety. One hundred broilers were grouped into 5 treatments and 4 replications, each group consisting of 5 heads. FLC was given in drinking

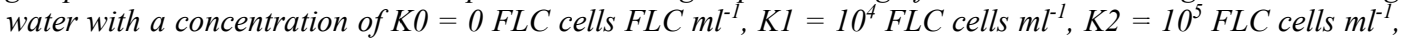
$\mathrm{K}^{3}=10^{6} \mathrm{FLC}$ cells $\mathrm{ml}^{-1}, \mathrm{~K} 4=10^{7} \mathrm{FLC}$ cells $\mathrm{ml}^{-1}$. The parameters measured; 1) broiler performance: feed consumption (g), body weight (g), feed conversion, carcass percentage (\%); 2) broiler blood cholesterol (mg $d l^{-1}$ ). The results showed that supplementation with a concentration of $10^{7}$ cells $F L C ~ m l^{-1}$ (K4) gave the best performance, body weight gain increased by $8.5 \%$ compared to control (K0). The ration conversion ranged from 1.23 to 1.25 and the percentage of carcass was $4.0 \%$ higher than the control. Blood cholesterol decreased in line with the increase in the provision of FLC in drinking water, which was between $135 \mathrm{dl}^{-1}$ (K0) down to $125 \mathrm{mg} \mathrm{dl^{-1 }}$ (K4). Application of FLC in drinking water with a concentration of $10^{7} \mathrm{cells} \mathrm{FLC} / \mathrm{ml}$, can improve performance and reduce broiler blood cholesterol for food safety.
\end{abstract}

Keywords:broiler; fresh liquid Chlorella; carcass; blood cholesterol level; food savety

\begin{abstract}
Abstrak:Mikroalga sudah lama dipelajari sebagai makanan fungsional dan sebagai food supplement untuk kesehatan. Mikroalga mengandung nutrisi yang berperan sebagai antimikroba, antioksidan alami, antikolesterol serta mengandung hormon pertumbuhan (growth hormon). Tujuan penelitian adalah untuk mengetahui aplikasi fresh liquid Chlorella (FLC) sebagai suplemen alami terhadap performa dan kolesterol darah broiler untuk keamanan pangan. Seratus ekor broiler dikelompokkan dalam 5 perlakuan dan 4 ulangan

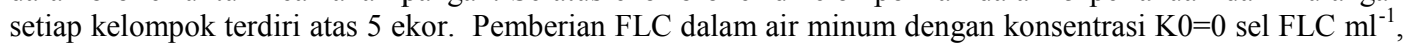
$\mathrm{K} 1=10^{4}$ sel FLC ml ${ }^{-1}, \mathrm{~K} 2=10^{5}$ sel FLC ml ${ }^{-1}, \mathrm{~K} 3=10^{6}$ sel FLC ml ${ }^{-1}, \mathrm{~K} 4=10^{7} \mathrm{sel} \mathrm{FLC} \mathrm{ml}{ }^{-1}$. Parameter yang diukur; 1) performa broiler yaitu; konsumsi ransum (g), pertambahan bobot badan (g), konversi ransum, persentase karkas (\%). 2) kolesterol darah broiler $\left(\mathrm{mg} \mathrm{dl}^{-1}\right)$. Hasil penelitian menunjukkan pemberian suplemen

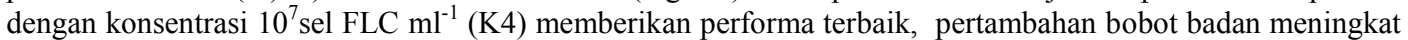
8,5\% dibandingkan kontrol (K0). Konversi ransum berkisar antara 1,23-1,25 dan persentase karkas lebih tinggi 4,0\% dibanding kontrol. Kolesterol darah menurun sejalan dengan peningkatan pemberian FLC dalam air minum yaitu antara $135 \mathrm{mg} \mathrm{dl}^{-1}$ (K0) turun hingga $125 \mathrm{mg} \mathrm{dl}^{-1}$ (K4). Aplikasi FLC dalam air minum dengan konsentrasi $10^{7}$ sel FLC $\mathrm{ml}^{-1}$ dapat memperbaiki performa, dan menurunkan kolesterol darah broiler untuk keamanan pangan.
\end{abstract}

Kata kunci:broiler; fresh liquid Chlorella; karkas; kolesterol darah; keamanan pangan

\section{PENDAHULUAN}

Dimasa pandemi virus Covid-19 seperti saat ini, setiap orang berpeluang terinfeksi. Pencegahan bisa dilakukan dengan cara melakukan physical distancing, lebih banyak berada di dalam rumah dan memakan makanan yang bergizi terutama protein, karena antigenmerupakan bagian dari proteinyang berperan dalam menjaga ketahanan tubuh secara alami. Cukup banyak bahan makan yang mengandung protein baik nabati maupun yang berasal dari hewani, dan yang populer adalah ayam broiler. Sebagian masyarakat masih ada yang khawatir mengkonsumsi daging ayam broiler karena isue residu dan AGP (antibiotic growth 
promotor). Penggunaan suplemen dan AGP sintetis telah diatur dalam Undang-Undang No. 18/2009 juncto Undang-Undang No.41/2014 dan sejak 1 Januari 2018 pemerintah sudah melarang penggunaan AGP dalam pakan, sebagai pengganti, pemberian beberapa suplemen alami seperti jamu-jamuan sudah banyak dicobakan, namun suplemen yang belum banyak tereksflorasi adalah yang berasal dari mikroalga.

Mikroalga adalah fitoplankton yang biasa hidup di lingkungan perairan air tawar, laut maupun payau yang memiliki tingkat reproduksi yang tinggi (Krichen et al, 2019). Chlorellasp adalah mikroalga uniseluler hijau dengan sifat biologis dan farmakologis yang penting untuk kesehatan manusia. Chlorellasp mengandung komposisi nutrisi fungsional makro dan mikro termasuk protein, asam lemak tak jenuh ganda omega-3, polisakarida, vitamin dan mineral. Uji klinis menunjukkan bahwa suplementasi dengan Chlorella sp dapat memperbaiki hiperlipidemia dan hiperglikemia, dan melindungi terhadap stres oksidatif, kanker, dan penyakit paru obstruktif kronik (Panahi et al., 2016). Mikroalga juga berfungsi sebagai antimikroba, antioksidan alami, antikolesterol, danmengandung hormon pertumbuhan (growth hormon) (Harun et al., 2010). Chlorellasp dapat meningkatkan fungsi kekebalan dengan meningkatkan aktivitas berbagai bagian sistem kekebalan.

Disaat pandemiCOVID-19 ini, sangat penting untuk memilih makanan yang sehat untuk menjaga sistem kekebalan tubuh. Anda adalah apa yang anda makan. Makanan yang sehat berasal dari pakan yang sehat. Salah satu sumber makanan sehat yang kaya protein adalah ayam broiler. Dading ayam kaya akan vitamin B-6. Vitamin B-6 penting dalam banyak reaksi kimia seperti pembentukan sel darah merah barudi dalam tubuh. Rebusan tulang ayam mengandung gelatin, kondroitin, dan nutrisi lain yang bermanfaat untuk penyembuhan usus dan kekebalan. Untuk mendapatkan daging broiler yang ASUH (aman, sehat, utuh dan halal) perlu diberi pakan dan suplemen yang juga ASUH (Salvia et al., 2014). Suplementasi diet unggas dengan Chlorella vulgarisdalam bentuk mash, terbukti meningkatkan populasi mikroflora dalam saluran pencernaan, mengurangi kadar kolesterol total telur dan meningkatkan asam lemak omega-3 (Janczyk, 2009 dalam Jacob, 2013).

Suplementasi mikroalga dalam bentuk mash harganya cukup mahal. Pada penelitian terdahulu telah dicoba memberikan suplemen Chlorellasp dalam bentuk fresh liquid Chlorella (FLC)pada broiler untuk mengurangi biaya pakan. Hasil penelitian menunjukkan bahwa, pemberian suplemen dengan kerapatan

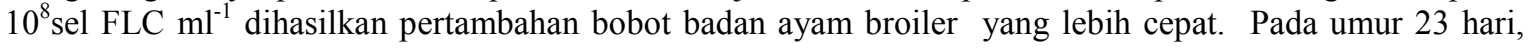
$22 \%$ dari populasi ayam broiler telah mencapai berat $1,2 \mathrm{~kg}$ (berat jual) sedangkan ayam kontrol baru mencapai $12 \%$. Hal ini membuktikanbahwa, FLC dapat berfungsi sebagai growth promotor alami untuk memacu pertumbuhan dan memperbaiki performa ayam broiler (Salviaet al, 2019).

Sampai saat ini batasan pemberian Chlorellasp dalam belum FLC yang aman pada broiler belum diketahui.Beberapa studi mencantumkan pemakaian Chlorella sp bentuk mash maksimal 10\% dalam ransum. Tingkat pemakaian yang lebih tinggi akan menghasilkan kinerja pertumbuhan yang buruk (Sujatha and Nagarajan, 2011). Penelitian secara bioassay merupakan salah satu cara untuk dapat memenuhi kriteria status keamanan pangan yang dipersyaratkan diantaranya kolesterol. Dengan demikian produk yang dihasilkan terjamin ASUH, sehingga tidak membahayakan kesehatan dan keselamatan konsumen (Koyande et al., 2019).Tujuan penelitian adalah untuk mengetahui aplikasi fresh liquid Chlorella (FLC) sebagai suplemen alami terhadap performa dan kolesterol darah broiler untuk keamanan pangan.

Mikroalga adalah fitoplankton yang biasa hidup di lingkungan perairan air tawar, laut maupun payau yang memiliki tingkat reproduksi yang tinggi (Krichen et al, 2019). Chlorellasp adalah mikroalga uniseluler hijau dengan sifat biologis dan farmakologis yang penting untuk kesehatan manusia. Chlorellasp mengandung komposisi nutrisi fungsional makro dan mikro termasuk protein, asam lemak tak jenuh ganda omega-3, polisakarida, vitamin dan mineral. Uji klinis menunjukkan bahwa suplementasi dengan Chlorella sp dapat memperbaiki hiperlipidemia dan hiperglikemia, dan melindungi terhadap stres oksidatif, kanker, dan penyakit paru obstruktif kronik (Panahi et al., 2016). Mikroalga juga berfungsi sebagai antimikroba, antioksidan alami, antikolesterol, danmengandung hormon pertumbuhan (growth hormon) (Harun et al., 2010). Chlorellasp dapat meningkatkan fungsi kekebalan dengan meningkatkan aktivitas berbagai bagian sistem kekebalan.

Disaat pandemiCOVID-19 ini, sangat penting untuk memilih makanan yang sehat untuk menjaga sistem kekebalan tubuh. Anda adalah apa yang anda makan. Makanan yang sehat berasal dari pakan yang sehat. Salah satu sumber makanan sehat yang kaya protein adalah ayam broiler. Dading ayam kaya akan vitamin B-6. Vitamin B-6 penting dalam banyak reaksi kimia seperti pembentukan sel darah merah barudi dalam tubuh. Rebusan tulang ayam mengandung gelatin, kondroitin, dan nutrisi lain yang bermanfaat untuk penyembuhan usus dan kekebalan. Untuk mendapatkan daging broiler yang ASUH (aman, sehat, utuh dan halal) perlu diberi pakan dan suplemen yang juga ASUH (Salvia et al., 2014). Suplementasi diet unggas dengan Chlorella vulgarisdalam bentuk mash, terbukti meningkatkan populasi mikroflora dalam saluran 
pencernaan, mengurangi kadar kolesterol total telur dan meningkatkan asam lemak omega-3 (Janczyk, 2009 dalam Jacob, 2013).

Suplementasi mikroalga dalam bentuk mash harganya cukup mahal. Pada penelitian terdahulu telah dicoba memberikan suplemen Chlorellasp dalam bentuk fresh liquid Chlorella (FLC)pada broiler untuk mengurangi biaya pakan. Hasil penelitian menunjukkan bahwa, pemberian suplemen dengan kerapatan $10^{8}$ sel FLC $\mathrm{ml}^{-1}$ dihasilkan pertambahan bobot badan ayam broiler yang lebih cepat. Pada umur 23 hari, $22 \%$ dari populasi ayam broiler telah mencapai berat $1,2 \mathrm{~kg}$ (berat jual) sedangkan ayam kontrol baru mencapai $12 \%$. Hal ini membuktikanbahwa, FLC dapat berfungsi sebagai growth promotor alami untuk memacu pertumbuhan dan memperbaiki performa ayam broiler (Salviaet al, 2019).

Sampai saat ini batasan pemberian Chlorellasp dalam belum FLC yang aman pada broiler belum diketahui.Beberapa studi mencantumkan pemakaian Chlorella sp bentuk mash maksimal 10\% dalam ransum. Tingkat pemakaian yang lebih tinggi akan menghasilkan kinerja pertumbuhan yang buruk (Sujatha and Nagarajan, 2011). Penelitian secara bioassay merupakan salah satu cara untuk dapat memenuhi kriteria status keamanan pangan yang dipersyaratkan diantaranya kolesterol. Dengan demikian produk yang dihasilkan terjamin ASUH, sehingga tidak membahayakan kesehatan dan keselamatan konsumen (Koyande et al., 2019).Tujuan penelitian adalah untuk mengetahui aplikasi fresh liquid Chlorella (FLC) sebagai suplemen alami terhadap performa dan kolesterol darah broiler untuk keamanan pangan.

\section{METODE}

Alat dan Bahan

Isolat mikroalga uji,medium kultur Phyto-s untuk produksi masa, galon, tabung reaksi, pipet, mikroskop, mikropipet 10-100 $\mu$, hemasitometer, autoklaf, lampu TL 40 watt dan aerator, kandang metabolis.

Seratus ekor DOC strainLohman (MB 202)produksi PT. Japfa Comfeed Indonesia.Ransum basal (BR1) produksi Jabfa dengan kandungan protein kasar (PK) 20,5\% energi metabolis $3.025 \mathrm{kkal} \mathrm{kg}^{-1}$. Ransum perlakuan (ransum basal BR1yang disubstitusi dengan 10\% dedak dengan kandungan protein kasar (PK) 19,5\% dan energi metabolis (ME) $2950 \mathrm{kkal} \mathrm{kg}^{-1}$.Suplemen yang diujikan berupa Chlorella sp dalam bentuk segar (fresh liquid Chlorella) yang ditambahkan ke dalam air minum dengan kerapatan sel yang berbeda.

\section{Tahapan penelitian \\ Peremajaan dan produksi FLC}

Air sumur sebanyak 20 liter sebagai medium kultur, kemudian ditambahkan nutrisiPhyto-s lalu di sterilkan. Medium kultur kemudian di masukkan ke dalam galon. Selanjutnya ditambahkan isolat dengan kerapatan 20.000 selml $^{-1}$ untuk setiap $1 \mathrm{~L}$ medium kultur. Kultur diberi aerator dan diletakkan pada tempat terbuka dengan pencahayaan matahri penuh. Peremajaan kultur dilakukan selama 15 hari atau dengan kerapatan sel mencapai $10^{8} \mathrm{sel} / \mathrm{ml}$. Perhitungan kultur dilakukan dengan menggunakan sedgwick rafter di bawah mikroskop dengan bantuan hand colony counter.

\section{Penyiapan hewan percobaan.}

Seratus ekor DOC strainLohman (MB 202) ditimbang satu per satu, kemudian dialokasikan ke dalam 20 unit kandang percobaan secara acak. Setiap kelompok terdiri dari 5 ekor DOC. Sebagai perlakuan adalah konsntrasi FLC yang diberikan melalui air minum dengan kerapatan yang berbeda yaitu :

$$
\begin{aligned}
& \mathrm{K} 0=0 \mathrm{sel} \mathrm{FLC} \mathrm{ml}^{-1} \text { air minum } \\
& \mathrm{K} 1=10^{4} \mathrm{sel} \mathrm{FLCml}^{-1} \text { air minum } \\
& \mathrm{K} 2=10^{5} \mathrm{sel} \mathrm{FLCml}^{-1} \text { air minum } \\
& \mathrm{K} 3=10^{6} \mathrm{sel} \mathrm{FLCml}^{-1} \text { air minum } \\
& \mathrm{K} 4=10^{7} \mathrm{sel} \mathrm{FLCml}^{-1} \text { air minum }
\end{aligned}
$$

Pemberian FLC dalam air minum dilakukan setiap hari secara ad-libitum. Kelompok kontrol diberi ransum basal dengan PK 20,5 \% dan kelompok perlakuan diberi ransum perlakuan dengan PK 19,5\%.

\section{Prosedur pelaksanaan analisis kadar kolesterol.}

Reagen (kit) Cholesterol diasys dipipetkan ke dalam tabung reaksi kemudian ditambahkan supernatan sebanyak $10 \mu \mathrm{l}$, Kemudianvortex dan didiamkan selama 20 menit pada suhu kamar atau 10 menit di dalam waterbath pada suhu $37^{\circ} \mathrm{C}$ sampai terbentuk warna pink. Seterusnya dibuat larutan blanko sebagai pembanding dengan cara, dipippet 1,0 $\mathrm{ml}$ kit kolesterol dimasukkan ke dalam tabung reaksi. Setiap satu seri analisa dibuatkan satu seri blanko. Blanko dimasukkan ke dalam spektrofotometer, diatur panjang gelombang pada $630 \mathrm{~nm}$, dan angka yang tertera dimonitor menunjukkan nol. Selanjutnya dimasukkan 
sampel yang akan diukur. Catat angka yang tertera di monitor yang menunjukkan serapan sampel. Prosedur yang sama juga dilakukan untuk pengukuran serapan standar.

\section{Peubah yang diamati.}

Peubah yang diamati adalah; performa (konsumsi ransum, pertambahan bobot badan, konversi ransum, persentase karkas), dan kandungan kolesterol serum darah broiler.

\section{Rancangan percobaan dan analisis data}

Penelitian ini menggunakan Rancangan Acak Lengkap (RAL). Sebagai perlakuan adalah 5 konsentrasi FLC dengan ulangan 4 kali. Data yang diperoleh dianalisis secara statistik dengan menggunakan sidik ragam sesuai rancangan yang digunakan. Untuk melihat perbedaan diantara perlakuan diuji lanjut dengan DMRT pada tingkat 5\%. Semua analisis yang dilakukan menggunakan prosedur Steel dan Torrie (1991). Data diolah menggunakan aplikasi SPSS versi 17.

\section{HASIL DAN PEMBAHASAN}

\section{Performa Broiler}

Performa broiler (konsumsi ransum, pertambahan bobot badan, konversi ransum dan persentase karkas broiler ) selama 3 minggu pengamatan yang diberi suplemen FLC bisa dilihat pada Tabel 1.

Tabel 1. Performa dan kolesterol darah broiler yang diberi FLC selama 3 minggu pengamatan

\begin{tabular}{|c|c|c|c|c|c|}
\hline \multirow{2}{*}{ Parameter } & \multicolumn{5}{|c|}{ Perlakuan } \\
\hline & K0 & K1 & $\mathrm{K} 2$ & K3 & K4 \\
\hline Konsumsi (g ekor ${ }^{-1}$ ) & $642,9^{a}$ & $650,0^{a}$ & $660,2^{b}$ & $689,8^{\mathrm{c}}$ & $694,2^{c}$ \\
\hline $\begin{array}{l}\text { Pertambahan bobot badan } \\
\left(\text { g ekor }^{-1}\right)\end{array}$ & $494,0^{\mathrm{a}}$ & $498,0^{\mathrm{a}}$ & $508,8^{\text {ab }}$ & $529,0^{\mathrm{b}}$ & $540,2^{\mathrm{c}}$ \\
\hline Konversi & $1,30^{\mathrm{a}}$ & $1,31^{\mathrm{a}}$ & $1,29^{\mathrm{a}}$ & $1,30^{\mathrm{a}}$ & $1,29^{\mathrm{a}}$ \\
\hline Persentase karkas (\%) & $67,96^{\mathrm{a}}$ & $69,18^{a b}$ & $70,04^{b}$ & $70,03^{b c}$ & $70,80^{\mathrm{c}}$ \\
\hline Kolesterol darah $\left(\mathrm{mgdl}^{-1}\right)$ & 135,00 & 133,00 & 127,00 & 127,00 & 125,00 \\
\hline
\end{tabular}

Keterangan : angka yang diikuti oleh huruf yang berbeda pada baris menunjukkan perbedaan yang nyata $(\mathrm{P}<0,5)$

Tabel 1. memperlihatkan performa broiler yang diberi suplemen FLC. Hasil analisis sidik ragam menunjukkan bahwa pemberian suplemen FLC selama 3 minggu berpengaruh nyata $(\mathrm{P}<0.05)$ terhadap konsumsi ransum. Rataan konsumsi ransum meningkat pada perlakuan K2 (660,2 $\left.\mathrm{g} \mathrm{ekor}^{-1}\right)$ kemudian diikuti oleh K3 (698,8 g ekor $\left.^{-1}\right)$ dan K4 (694,2 g ekor $\left.^{-1}\right)$. Dapat dinyatakan bahwa konsumsi ransum meningkat dengan meningkatnya pemberian suplemen FLC. Hal ini memungkinkan karena Chlorella sp merupakan prebiotik yang dapat meningkatkan populasi mikroflora usus. Hal ini dinyatakan oleh Jacob (2013) bahwa Chlorella spdapat meningkatkan populasi mikroflora dalam usus sehingga kinerjanya dalam mencerna pakan meningkat dan aliran pakan dalam usus lebih cepat sehingga usus lebih cepat kosong dan akhirnya ternak termotifasi untuk mengkonsumsi ransum lebih banyak.

Meningkatnya konsumsi ransum pada perlakuan K3 dan K4 berpengaruh terhadap pertambahan bobot badan. Selama 3 minggu pengamatan bobot badan perlakuan K3 (529,0 g ekor $\left.{ }^{-1}\right)$ dan K4 (540,0 g ekor $\left.^{-1}\right)$ ternyata lebin tinggi dibanding kontrol K0 ( 494,0 g ekor $\left.^{-1}\right)$ dengan peningkatan berturut turut $6,6 \%$ dan 8,5 \%. Hal ini memungkinkan karena Chlorella sp mengandung zat nutrisi sehingga dapat melengkapi kekurangan protein ransum. Dinyatakan oleh Harus et al., (2010) bahwa Chlorella sp merupakan suplemen yang mengandung makro dan mikro-nutrien seperti protein, beberapa vitamin (vitamin A, B, B1, B2, B6, B12, C, E, nikotin, biotin, asam folat, dan asam pantotenat) dan mineral penting lainnya. Hal senada juga dinyatakan oleh Kwak et al., (2012), bahwa mikroalga termasuk Chlorella mengandung bahan-bahan organik seperti polisakarida, hormon, vitamin, mineral dan juga senyawa bioaktif sehingga dapat menutupi kekurangan nutrisi ransum.

Dari hasil analisis sidik ragam, konversi ransum untuk semua perlakuan tidak berbeda nyata $(\mathrm{P}>0.05)$. Dengan demikian dapat dinyatakan bahwa broiler yang diberi suplemen FLC cukup efisien dalam merobah makanan menjadi bobot badan ayam broiler.

Persentase karkas merupakan pembagian berat karkas dengan berat hidup dikali $100 \%$.Bobot karkas dipengaruhi oleh bobot badan, sehingga bobot badan yang tinggiakan diikuti oleh karkas yang tinggi. Lemak abdomen dan jeroan juga berpengaruh terhadap persentase karkas. Jika lemak abdomen tinggi maka 
persentase karkas akan rendah. Hasil analisis sidik ragam menunjukkan bahwa pemberian suplemen FLC memberikan pengaruh nyata $(\mathrm{P}<0.05)$ terhadap persentase karkas. Selama 3 minggu pengamatan, perlakuan K4 menghasilkan persentase karkas paling baik $(70,80 \%)$ atau 4,0\% lebih tinggi dari K0 (kontrol) . Meningkatnya persentase karkas disebabkan karena FLC mengandung nutrisi yang mampu meningkatkan bobot badan ayam broiler sehingga bobot karkasnya pun meningkat, tetapi pemberian suplemen K1 $\left(10^{4}\right.$ sel FLC ml${ }^{-1}$ ) ternyata belum mampu meningkatkan persentase karkas. Selanjutnya Fouad dan Senousey (2014) menyatakan bahwa pakan merupakan salah faktor yang dapat mempengaruhi persentase karkas.Chlorella spadalah bahan pakan sumber protein, lemak, karbohidrat, serat, klorofil, vitamin, dan mineral yang baik yang dapat memperbaiki penampilan ternak karena perannya sebagai antioksidan dan dalam metabolisme lemak. Dinyatakan juga oleh Chen et al., (2011) bahwa mikroalga kaya akan pigmen sepertichloropyll, karotenoid, dan beta-carotene dan phycobili-protein, asam lemak omega-3 (PUFA n-3) yang dapat meningkatkan kualitas karkas broiler sehingga aman bagi yang mengkonsumsinya. Dengan demikian dapat diyakini bahwa pemberian suplemen FLC melalui air minum dapat meningkatkan performa broiler.

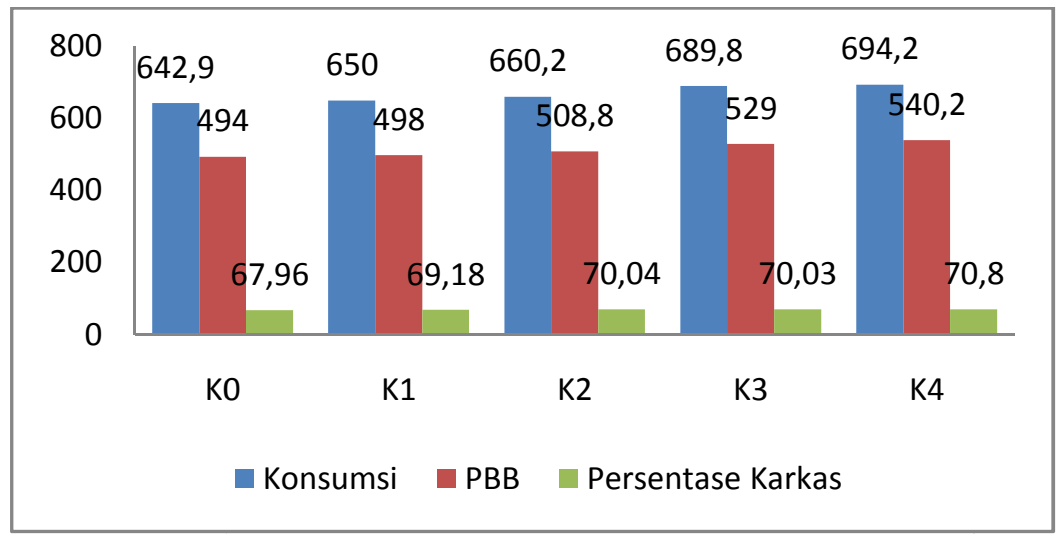

Gambar1. Performa broiler yang mengkonsumsi suplemen FLC

\section{Kolesterol Darah}

Tabel 1. juga memperlihatkan hasil penelitian level kolesterol darah broiler yang diberi suplemen FCL. Level kolesterol darah menurun sejalan dengan peningkatan konsumsi FLC. Level kolesterol turun $10 \mathrm{mgdl}^{-1}$ dari $135 \mathrm{mg} \mathrm{dl}^{-1}$ (K0) hingga $125 \mathrm{mgdl}^{-1}(\mathrm{~K} 4)$. Sejalan dengan penelitian yang telah dilakukan oleh Charles et al., (2019) danLee et al, (2003) bahwapemberian suplemen mikroalga Chlorella dapat menurunkan kadar kolesterol darah broiler karena Chlorella mengandung vitamin C, vitamin E, mineral zn dan selenium. Vitamin E adalah antioksidan yang bekerja dalam tubuh yang mengandung lemak, yaitu berperan dalam sistem oksidasi dan reduksi sehingga dapat menurunkan kolesterol dalam darah. Selenium berfungsi sebagai komponen dari sejumlah enzim diantaranya gluthatione peroksidase. Semakin tinggi asupan vitamin E dan selenium, semakin rendah kadar kolesterol darah (Komsam, 2003). Selain itu Chlorella sp juga mengandung asam lemak omega 3, asam lemak omega 6, dan asam lemak omega 9 yang merupakan asam lemak tak jenuh. Asam lemak omega 3 dapat menurunkan kadar LDL kolesterol dan meningkatkan kadar HDL kolesterol serta menurunkan resiko terjadinya pembekuan dalam pembuluh darah. Selain itu,suplementasi Chlorella dapat meningkatkan mikroflora usus yang berperan penting dalam mekanisme kolesterol darah (Janczyk, 2009 dalam Jacob, 2013). 


\section{Kolesterol Darah mg/dl}

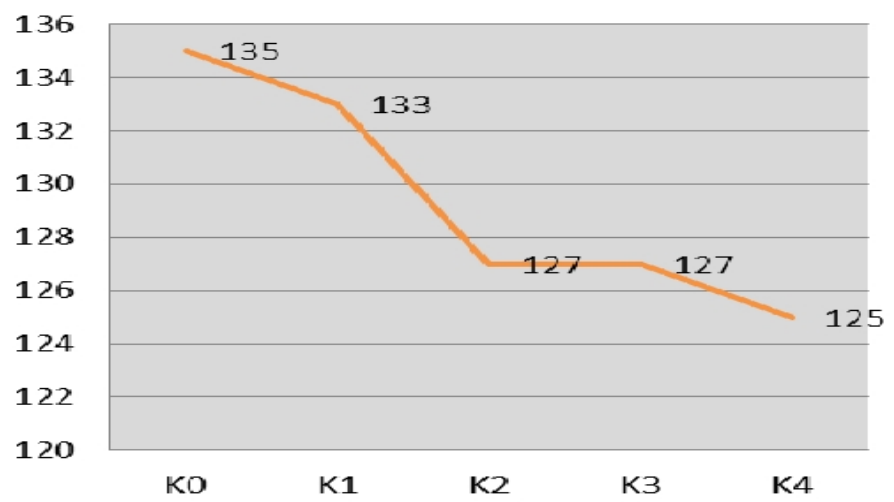

Gambar 2. Penurunan level kolesterol darah broiler yang mengkonsumsi suplemen

FLC

Berdasarkan penelitian ini, dapat dinyatakan bahwa pemberian suplemen FLC pada taraf $10^{7}$ sel FLC $\mathrm{ml}^{-1}$ adalah yang terbaik diaplikasikan untukmeningkatkan performa dan menurunkan level kolesterol darah broiler.

\section{KESIMPULAN}

Aplikasi fresh liquid Chlorella (FLC) dalam air minum dengan kerapatan $10^{7}$ sel $\mathrm{FLC} \mathrm{ml}^{-1}$ (K4) adalah yang terbaik dalam meningkatkan performa dan menurunkan level kolesterol darah broiler. Selama 3 minggu pengamatan bobot badan meningkat 8,5\% dan persentase karkas lebih tinggi 4,0\% dibanding kontrol serta kolesterol darah broiler turun $10 \mathrm{mgdl}^{-1}$. Ayam broiler yang diberi suplemen fresh liquid Chlorella (FLC) diharapkan dapat menjadi sumber protein hewani rendah kolesterol dan ASUH untuk keamanan pangan, terutama dimasa pandemi Covid-19 ini supaya daya tahan tubuh tetap kuat.

\section{UCAPAN TERIMA KASIH}

Ucapan terima kasih tak terhingga kepada Politeknik Pertanian Negeri Payakumbuh yang telah mendanai penelitian ini. Ucapan terima kasih juga disampaikan kepada Pusat Penelitian dan Pengabdian Kepada Masyarakat, Politeknik Pertanian Negeri Payakumbuh dan semua pihak yang telah membantu.

\section{REFERENSI}

Charles C. N., T. Msagati, H. Swai, M. Chacha. 2019. Microalgae: An alternative natural source of bioavailable omega-3 DHA for promotion of mental health in East Africa. Scientific African. Volume 6, November 2019, e00187

Chen, C.H., K.L Yeh., R. Aisyah, D.J. Lee, J.S. Chang. 2011. Cultivation, photobioreactor design and harvesting of microalgae for biodiesel production: a critical review. Bioresource Technology. Nomor 102: 71-81.

FouadA. M. H. K. El-Senousey. 2014. Nutritional factors affecting abdominal fat deposition in poultry: A Review. Asian-Australas J Anim Sci. 2014 Jul; 27(7): 1057-1068.PMID: 25050050

Harun, R., M. Singh., G.M. Forde, dan M.K. Danquah. 2010. Bioprocess engineering of microalgae to produce a variety of consumer products. Renewable and sustainable energy reviews 14: 1037-1047.

Jacob, J. 2013. Use of micro-algae in organic poultry diets. organic agriculture. University of Kentucky. america's research-based learning network.http:/www.extension.org/ pages/70178/use-of-microalgae-in-organic-poultry-diets.

Koyande,A. K., K. W. Chew, K. Rambabu, D. Chu, P. Show. 2019. Microalgae: a potential alternative to health supplementation for humans. Food Science and Human Wellness. Vol 8 (1), pp 16-24

Krichen E., A. Rapaport, E. L. Floc'h, and E. Fouilland.2019. Demonstration of facilitation between microalgae to face environmental stress. Sci Rep. 2019; 9: 16076. Published online 2019 Nov 5. doi: 10.1038/s41598-019-52450-9.

Komsam, A., 2003. Pangan dan gizi untuk kesehatan. PT. Rajagrafindo Persada, Jakarta. 
Kwak J. H, S. H. Baek, Y. Woo, J. K. Han, B. G. Kim, O. Y. Kim and J. H. Lee. 2012. Beneficial immunostimulatory effect of short-term chlorella supplementation: enhancement of natural killer cell activity and early inflammatory response (randomized, double-blinded, placebo-controlled trial). Nutr J. 2012; 11: 53. doi: 10.1186/1475-2891-11-53.

Lee. 2003. Supergreen food (SGF) new formula. http://network.detoksalami.com/produk_detail.php?\&id=2 (diunduh tanggal 31 Maret 2014).

Panahi, Y., B. Darvishi, N. Jowzi, F. Beiraghdar, A. Sahebkar. 2016. Chlorella vulgaris: a multifunctional dietary supplement with diverse medicinal properties. Curr Pharm Des. 2016;22(2):164-73. doi: $10.2174 / 1381612822666151112145226$.

Salvia. S., R. Novia., I. Irda. 2019. The influence of chlorella sp as supplement and efficiency of broiler feed. Proceeding 3rd International conference. Politeknik Pertanian Negeri Payakumbuh. November.

Salvia. S., Mirzah., Y. Marlida dan E. Purwati. 2014. The optimizing of growth and quality of chlorella vulgaris as asuh feed supplement for broiler. J. Advanced Science Engineering Information Technology 4 (4): pp 90-93.PMID: 26561078

Steel, R.G.D. dan J.H. Torrie. 1991. Prinsip dan prosedur statistika. Diterjemahkan oleh Bambang Sumantri. PT. Gramedia pustaka utama. Jakarta

Sujatha, K., and P. Nagarajan. 2011. Optimization of growth conditions for carotenoid production from spirulina platensis (Geitler). Int. J. Current Microbiol. App Sci. 2(10). pp 325-328. 